\title{
Evaluation of the efficacy of cypermethrin and amitraz against Rhipicephalus (Boophilus) microplus, in the State of Pernambuco, Brazil
}

\author{
Avaliação da eficácia de cipermetrina e amitraz contra Rhipicephalus \\ (Boophilus) microplus no estado de Pernambuco, Brasil
}

\section{Breno Barros de Santana', Rafael Antonio Nascimento Ramos ${ }^{2,3}$, Maria Aparecida da Gloria Faustino², Leucio Câmara Alves², Gílcia Aparecida de Carvalho ${ }^{1 *}$}

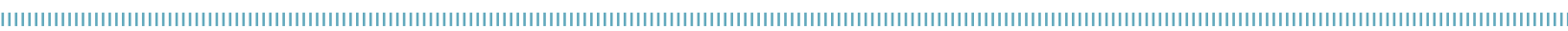

\begin{abstract}
The Rhipicephalus (Boophilus) microplus is an important tick species which affect bovines in tropical areas. Its control is based on the use of chemical acaricides, but the frequent use of these substances has been conducted to the development of tick resistance. The aim of this study was to assess the efficacy of cypermethrin and amitraz against $R$. (B.) microplus collected of bovines from different municipalities of the state of Pernambuco. From August 2009 to July 2011, engorged females were collected and subjected to the "Adult Immersion Test" in order to evaluate the efficacy of cypermethrin and amitraz. The results indicate that populations of $R$. (B.) microplus from Pernambuco present resistance to acaricides (i.e., cypermethrin and amitraz). In this study, a single population (Brejo da Madre de Deus) was susceptible to cypermethrin, whereas two (Timbaúba and Limoeiro) were susceptible to amitraz. Data herein reported follow a pattern observed in other regions of Brazil and alert to the fact that alternative measures of control should be implemented in this area studied.
\end{abstract}

KEYWORDS: ticks; cypermethrin; amitraz; bovine; Pernambuco.
RESUMO: Rhipicephalus (Boophilus) microplus é uma importante espécie que acomete bovinos em áreas tropicais. $\mathrm{O}$ controle desse carrapato se baseia no uso de acaricidas químicos, mas a utilização frequente dessas substâncias tem conduzido ao desenvolvimento de resistência. O objetivo deste estudo foi avaliar a eficácia da cipermetrina e do amitraz contra $R$. (B.) microplus coletadas de bovinos de diferentes municípios do estado de Pernambuco. De agosto de 2009 a julho de 2011, as fêmeas ingurgitadas foram coletadas e submetidas ao Adult Immersion Test, a fim de avaliar a eficácia de cipermetrina e amitraz. Os resultados indicam que as populaçôes de $R$. (B.) microplus de Pernambuco apresentaram resistência aos acaricidas (cipermetrina e amitraz). Neste estudo, uma única população (Brejo da Madre de Deus) foi suscetível à cipermetrina, enquanto duas (Timbaúba e Limoeiro) foram sensíveis ao amitraz. Os dados aqui relatados seguem um padrão observado em outras regióes do Brasil e alertam para o fato de que as medidas alternativas de controle devem ser implementadas na área estudada.

PALAVRAS-CHAVE: carrapatos; cipermetrina; amitraz; bovino; Pernambuco.

'Universidade Federal Rural de Pernambuco/Unidade Acadêmica de Garanhuns (UFRPE/UAG) - Garanhuns (PE), Brasil.

²Departamento de Medicina Veterinária, Laboratório de Doenças Parasitarias dos Animais Domésticos, UFRPE - Recife (PE), Brasil.

${ }^{3}$ Università degli Studi di Bari, Dipartimento di Medicina Veterinaria - Valenzano, Italy.

*Corresponding author: gilciasilva@yahoo.com.br

Received on: 10/12/2013. Accepted on: 23/10/2015 
The Rhipicephalus (Boophilus) microplus (CANESTRINI, 1888) is the most important tick species which affect bovines in tropical areas, causing economical losses and transmitting pathogens (DANTAS-Torres, 2007). Its control is based on the use of chemical compounds, being the arsenicals the first substance used, followed by organochlorids and organophosphorids (Graf et al., 2004). At the end of the last century, compounds such as formamidines and synthetic pyrethoids acquired a great importance in the control of ixodids (BENAVIDES; Romero, 2002; Leal et al., 2003). However, the indiscriminate use of these substances has been conducted to the appearance of several cases of tick resistance (ARANTES et al., 1995). This phenomenon has been widely reported (Li et al., 2004; Rosado-Aguilar et al., 2008), including various descriptions in Brazil (CAmpos Júnior; Oliveira, 2005; Gomes et al., 2011), where there are reports in Rio Grande do Sul (Patarroyo; Costa, 1980), Minas Gerais, Espírito Santo (Leite et al., 1995), São Paulo (SoAres et al., 2001), Bahia and Pernambuco (Santana et al., 2013).

In the North and Northeast of Brazil, studies about the resistance of ticks are scarce (ANDREOTTI, 2010). In the state of Pernambuco, the resistance of $R$. (B.) microplus has been assessed in few studies (Santana et al., 2001; Santana et al., 2012), and the most recent evaluated only synthetic pyretroids and their associations (SANTANA et al., 2013). Therefore, the aim of this study was to assess the efficacy of cypermethrin and amitraz against $R$. (B.) microplus from different municipalities of the state of Pernambuco.

From August 2009 to July 2011, engorged females of $R$. (B.) microplus (150 specimens on each farm) were collected of naturally infested cattle from different municipalities of Pernambuco (Fig. 1). Ticks were subjected to the Adult Immersion Test (AIT) (Drummond et al., 1973; Santana et al., 2013), which is an in vitro resistance detection assay. The following commercial acaricides were used: (1) cypermethrin 10\%; (2) amitraz $12.5 \mathrm{~g}$. The dilutions of the products were realized following the manufacturer's instructions.

Briefly, 10 engorged females (per group) with homogeneous weight were placed in Petri dishes. The test groups were immersed in the acaricides for 5 minutes, and the controls were immersed in distilled water. The females were maintained in an incubator under controlled conditions $\left(26 \pm 1^{\circ} \mathrm{C}, 80 \pm 5 \%\right.$ relative humidity) for 16 days to lay eggs. After this had taken place, the eggs were placed in individual $10 \mathrm{~mL}$ glass vials, which were closed with a cotton plug and kept in the incubator under controlled conditions (see above). The acaricide efficiency $(\mathrm{AE})$ was obtained using the following parameters: engorged female weight, eggs weight and eggs hatching percentage. Finally, the chemical compounds were considered efficient whether $\mathrm{AE} \geq 95 \%$ (Drummond et al., 1973).

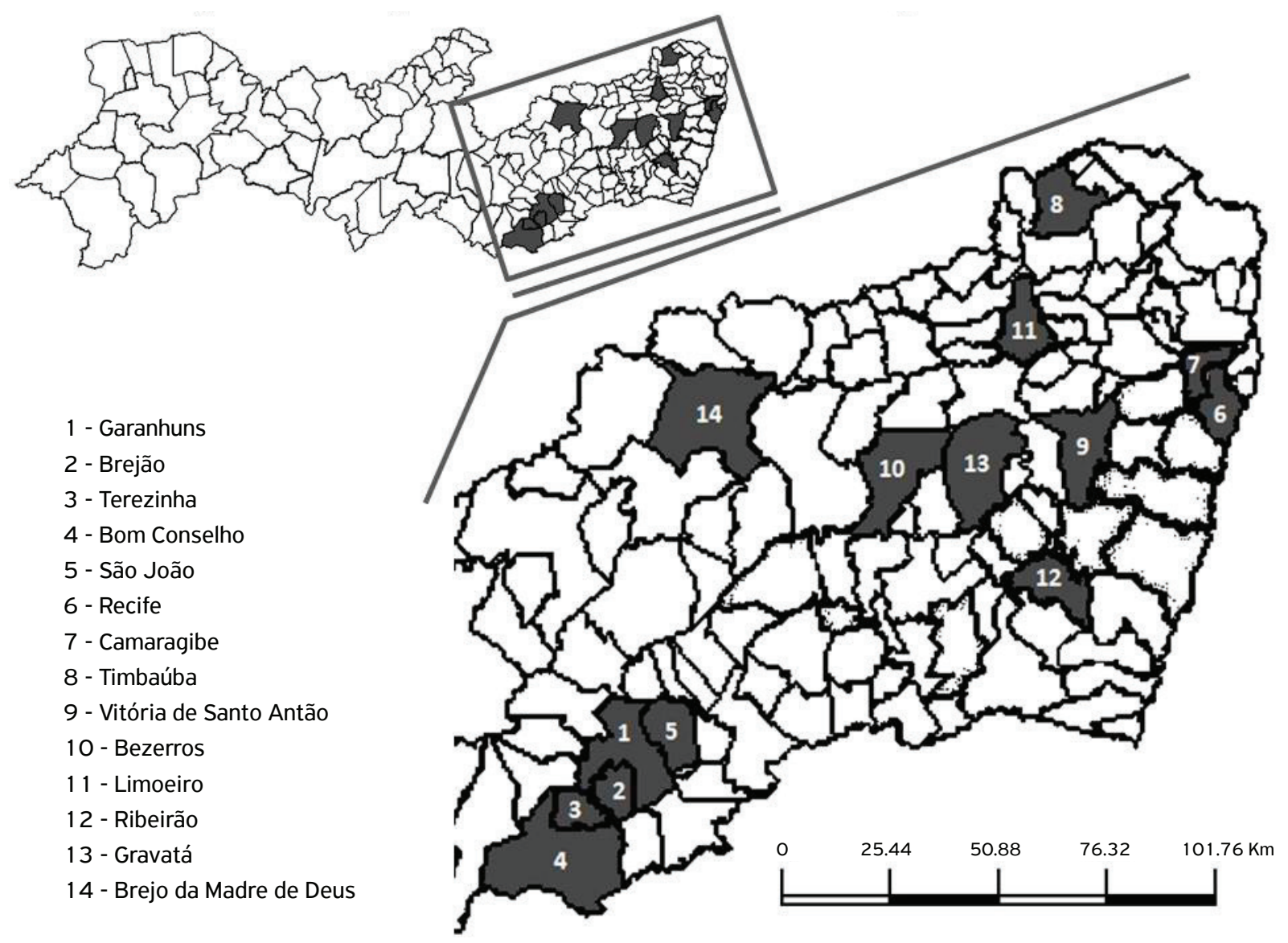

Figure 1. Municipalities studied in the state of Pernambuco. 
The overall results from the acaricide efficacy tests are reported in Table 1. The results indicate that populations of $R$. (B.) microplus from Pernambuco present resistance to acaricides (i.e., cypermethrin and amitraz). In particular, a single population (Brejo da Madre de Deus) was susceptible to cypermethrin, whereas two (Timbaúba and Limoeiro) were susceptible to amitraz.

The values of inefficacy for cypermethrin observed in this study follow a pattern observed in previous studies, demonstrating that the resistance to cypermethrin in $R$. (B.) microplus populations is widespread (SPAGNol et al., 2010; VeIGa et al., 2012). This event has been reported in several areas of Brazil (e.g., Rio Grande do Sul, São Paulo, Paraná, Mato Grosso do Sul, Minas Gerais and Rio de Janeiro) (Koller et al., 2009). Probably, the low performance of this chemical compound

Table 1. Mean efficacy (\%) of acaricides formulations against Rhipicephalus (Boophilus) microplus from different municipalities of Pernambuco, Brazil.

\begin{tabular}{lcc}
\multirow{2}{*}{ Municipalities } & \multicolumn{2}{c}{ Acaricide formulations/Efficacy } \\
\cline { 2 - 3 } & Cypermethrin & Amitraz \\
\hline Garanhuns & 23.61 & 45.70 \\
\hline Brejão & 26.68 & 48.60 \\
\hline Terezinha & 62.97 & 69.89 \\
\hline Bom Conselho & 32.75 & 25.50 \\
\hline São João & 53.37 & 48.60 \\
\hline Recife & 93.95 & 43.58 \\
\hline Camaragibe & 20.55 & 77.72 \\
\hline Timbaúba & 20.00 & 100.00 \\
\hline Vitória & 56.02 & 80.89 \\
\hline Bezerros & 58.95 & 78.70 \\
\hline Limoeiro & 55.90 & 100.00 \\
\hline Ribeirão & 6.74 & 15.64 \\
\hline Gravatá & 58.05 & 78.70 \\
\hline Brejo da Madre de Deus & 97.60 & 50.40 \\
\hline
\end{tabular}

is due to its frequent and indiscrimate use, which may select tick populations resistant to acaricides. Moreover, the crossresistance with other pyrethoids (e.g., deltametrhin and flumethrin) may be an additional factor that contributes for the resistance (Rosario-Cruz et al., 2009).

Similarly, the amitraz has been evaluated in several studies throughout the Brazil, presenting a wide variation of efficacy according to the $R$. (B.) microplus population studied. Percentages of inefficacy ranging from 30.95 to $88.75 \%$ have been reported in Bahia, Pernambuco, Minas Gerais and São Paulo (Arantes et al., 1995; Santana et al., 2001; Campos-Júnior; Oliveira, 2005; Mendes et al., 2007). Conversely, few studies report the efficacy of this compound (e.g., 98.13\%, Mendes et al., 2007) as observed herein for the populations of Timbaúba and Limoeiro. This wide variation of efficacy detected for amitraz might be due to the frequent use of this substance in several areas of the world (MarTins, 2006). In addition, the reversion of resistance, after 20 tick generation without the use of amitraz, may contribute for this variation (SPAGNol et al., 2010).

Unfortunately, data herein report represent a common situation observed in various Brazilians regions, where $R$. (B.) microplus is endemic. Particularly, in the state of Pernambuco, the incorrect use of these compounds has been reported as an important factor to the appearance of resistance (SANTANA et al., 2001; Santana et al., 2013). For example, the frequency of use of acaricides (more than four in a year), the under dosage, and the absence of environmental control are factors of risk which may select resistant populations (ARANTES et al., 1995; Santos et al., 2009). Finally, this study detected the presence of populations of $R$. (B.) microplus resistant to cypermethrin and amitraz in several municipalities of the state of Pernambuco. These data follow a pattern observed in other regions of Brazil and alert to the fact that alternative measures of control should be implemented in this area in order to obtain an appropriate control of these tick populations.

\section{REFERENCES}

ARANTES, G.J.; MARQUES, A.D., HOMER, M.R. O carrapato bovino, Boophilus microplus, no município de Uberlândia, MG. Análise da sua resistência contra carrapaticidas comerciais. Revista Brasileira de Parasitologia. Veterinária, v.4, n.2, p.89-93,1995.

ANDREOTTI, R. Situação atual da resistência do carrapato-do-boi Rhipicephalus (Boophilus) microplus aos acaricidas no Brasil. Campo Grande, MS: Embrapa Gado de Corte, 2010, 36 p. (Documentos/ Embrapa Gado de Corte, ISSN 1983-974X; 180). Disponível em:<http://www.cnpgc.embrapa.br/publicacoes/doc/DOC 180. pdf>. Acesso em: 12 jan. 2011.
BENAVIDES, E.; ROMERO, A. Consideraciones para el control integral de parásitos externos del ganado. Carta FEDEGAN, Edicion, n.70, p.1-7,2002.

CAMPOS JÚNIOR, D.A.; OLIVEIRA, P.R. Avaliação in vitro da eficácia de acaricidas sobre Boophilus microplus(Canestrini, 1887) (Acari: Ixodidae) de bovinos no município de Ilhéus, Bahia, Brasil.Ciência Rural, v.35, p.1387-1392, 2005.

DANTAS-TORRES, F. Rocky Mountain spotted fever. Lancet Infectious Diseases, v.7, p.724-732, 2007. 
DRUMMOND, R.O.; ERNST, S.E.; TREVINO, J.L.; GLADNEY, W.J.; GRAHAM, O.H. Boophilus annulatus and Boophilus microplus: laboratory tests of insecticides. Journal of Economic Entomology, v.66, n.1, p.130-133, 1973.

GOMES, A.; KOLLER,W.W.; BARROS, A.T.M. Suscetibilidade de Rhipicephalus (Boophilus) microplus a carrapaticidas em Mato Grosso do Sul, Brasil. Ciência Rural, v.41, n.8, p.1447-1452, 2011.

GRAF, J.F.; GOGOLEWSKI, N.; LEACH-BING, G.A.; SABATINI, M.B.; MOLENTO,E.L.; ARANTES, G.J. Tick control: an industry point of view. Parasitology, v.129 p.S427-S442, 2004.

KOLLER, W.W.; GOMES, A.; BARROS, A.T.M. Diagnóstico da resistência do carrapato-do-boi a carrapaticidas em Mato Grosso do Sul. Campo Grande - MS (Boletim de Pesquisa e Desenvolvimento/ Embrapa Gado de Corte). Campo Grande, MS. p.47 2009 Dados eletrônicos. Disponível em:<http://www.cnpgc.embrapa.br/ publicacoes/bp/BP25.pdf>. Acesso em: 10 jan. 2009.

LEAL, A.T.; FREITAS, D.R.J.; VAZ JUNIOR, I.S. Perspectivas para o controle do carrapato bovino. Acta Scientiae Veterinariae, v.31, p. 1-11, 2003.

LEITE, R.C.; LABRUNA, M.B.; OLIVEIRA, P.R.; MONTEIRO, A.M.F.; CAETANO JÚNIOR, J. In vitro susceptibility of engorged females from different populations of Boophilus microplus to comercial acaricides. Revista Brasileira de Parasitologia Veterinaria, v.4, n.2, p. 283-294, 1995. Suplemento 1.

LI, A.Y.; DAVEY, R.B.; MILLER, R.J.; GEORGE, J.E. Detection and characterization of amitraz resistance in the southern cattle tick, Boophilus microplus (Acari: Ixodidae). Journal of Medical Entomology, v.41, p.193-200, 2004.

MARTINS, J.R.S. Carrapato Boophilus microplus (Can. 1887) (Acari: Ixodidae) resistente a ivermectina, moxidectina e doramectina.2006. 74f. Tese (Doutorado em Ciência Animal) - Universidade Federal de Minas Gerais, 2006.

MENDES, M.C.; PEREIRA, J.R.; PRADO, A.P. Sensitivity of Boophilus microplus (Acari: Ixodidae) to pyrethroids and organophosphate in farms in the Vale do Paraíba Region, São Paulo, Brazil.Arquivos do Instituto Biológico, v.74, n.2, p. 81-85, 2007.

PATARROYO, J.H.; COSTA, J.O. Susceptibility of Brazilian samples of Boophilus microplus to organophosphorus acaricides. Tropical Animal Health and Production, v.12, n.1, p.6-10, 1980.

ROSADO-AGUILAR, J.A.; RODRIGUEZ-VIVAS, R.I.; GARCIAVAZQUEZ, Z.; FRAGOSO-SANCHEZ, H.; ORTIZ-NAJERA, O.;
ROSARIO-CRUZ, R. Development of amitraz resistance in field populations of Boophilus microplus (Acari: Ixodidae) undergoing typical amitraz exposure in the Mexican tropics. Veterinary Parasitology, v.152, p.349-353, 2008.

ROSARIO-CRUZ, R.; GUERRERO, F.D.; MILLER, R.J.; RODRIGUEZVIVAS, R.I.; TIJERINA, M.; DOMINGUEZ-GARCIA, D.I.; HERNANDEZ-ORTIZ, R.; CORNEL, A.J.; MACBEE, R.D.; ALONSODIAZ, M.A. Molecular survey of pyrethroid resistance mechanisms in Mexican field populations of Rhipicephalus (Boophilus) microplus. Parasitology Research, v. 105, n.4, p.1 145-1153, 2009.

SANTANA, V.L.A.; FAUSTINO, M.A.G.; LIMA, M.M.; FURLONG, J.; ALVES, L.C. Situação do controle químico do Boophilus na zona da mata e Agreste do Estado de Pernambuco. Ciência Veterinária nos Trópicos, v.4, n.2-3, p.281-290, 2001.

SANTANA, V.L.A.; FAUSTINO, M.A.G.;VANDERLEY, E.K.; LIMA, M.M.; ALVES, L.C.Evaluation of endectocides and conventional acaricides in the control of the Boophilus microplus on field-kept dairy cattle in the State of Pernambuco-Brazil.Open Journal of Veterinary Medicine,v.2, p.124-128, 2012.

SANTANA, B.B.; RAMOS, R.A.N.; SANTANA, M.A.; ALVES, L.C.; CARVALHO, G.A. Susceptibility of Rhipicephalus (Boophilus) microplus (Acari: Ixodidae) to pyrethroids and their associations in Pernambuco, Brazil.Revista Brasileira de Parasitologia Veterinária, v.22, n. 2, p. 276-280, 2013.

SANTOS, T.R.B.; FARIAS, N.A.R.; CUNHA FILHO, N.A.; VAZ JÚNIOR, I.S. Uso de acaricidas em Rhipicephalus (Boophilus) microplus de duas regiões fisiográficas do Rio Grande do Sul. Acta Scientiae Veterinarie, v.36, n.1, p.25-30, 2008.

SOARES, V.E.; SILVEIRA, D.M.; NUNES, T.L.S.; OLIVEIRA, G.P.; BARBOSA, O.F.; COSTA AJ. Análise in vitro da ação de carrapaticidas em cepas de Boophilus microplus (Canestrini, 1887) colhidas de bovinos leiteiros da região Nordeste do estado de São Paulo. Semina: Ciências Agrárias, v.22, n. 1, p. 85-90, 2001.

SPAGNOL, F.H.; PARANHOS, E.B.; ALBUQUERQUE, G.R. Avaliação in vitro da ação sobre o Rhipicephalus (Boophilus) microplus Canestrini, 1887(Acari:Ixodidae) de bovinos leiteiros no município de Itamaraju, Bahia, Brasil. Ciência Animal Brasileira, v. 1 1, n.3, p.731-736, 2010.

VEIGA, L.P.H.; SOUZA, A.P.; BELLATO, V.; SARTOR, A.A.; NUNES, A.P.O.; CARDOSO, H.M. Resistance to cypermethrin and amitraz in Rhipicephalus (Boophilus) microplus on the Santa Catarina Plateau, Brazil.Revista Brasileira de Parasitologia Veterinária, v.21, n.2, p.133-136, 2012. 